\title{
Novel Solar Powered Cold Water Dispenser
}

\author{
Samir M. Shariff \\ Electrical Engineering Department, Taibah University, Medinah, KSA \\ Email: samshariff@yahoo.com
}

How to cite this paper: Shariff, S.M. (2018) Novel Solar Powered Cold Water Dispenser. Journal of Power and Energy Engineering, 6, 33-37.

https://doi.org/10.4236/jpee.2018.62003

Received: November 16, 2017

Accepted: February 11, 2018

Published: February 14, 2018

Copyright (c) 2018 by author and Scientific Research Publishing Inc. This work is licensed under the Creative Commons Attribution International License (CC BY 4.0).

http://creativecommons.org/licenses/by/4.0/

\begin{abstract}
Solar powered cold water dispenser apparatus is fabricated and experimental results are shown in this work. The system contains solar panels, two low energy fans, water tank fabricated from clay (pottery), thermally sealed box, and pipes. Once these contents are connected together, testing was conducted on water temperatures at both ends. The preliminary results showed a drop in temperature of around $15^{\circ} \mathrm{C}$. This is achieved by utilizing free power from the sun.
\end{abstract}

\section{Keywords}

Solar Energy, Heat Transfer, Temperature Decrease, Cost Reduction, ROI

\section{Introduction}

In the past, solar energy has been used in many applications. Early usage of the sun was used in heating, worming up, and drying. The sun was a good source to build fires and produce energy. In the past two decades, many scientists and engineers have utilized solar energy. With more advancement in its technology, solar energy has emerged drastically. Increasing cost of oil production made it more cost effective to produce power via solar cells. Environmental issues and the ozone depletion added up to the usage of solar power [1]-[6].

Electric water coolers are scattered all over Saudi Arabia. As individuals, companies, and government agencies have placed these water coolers to overcome the hot and harsh environment in the country in order to help individuals. The existing water coolers are sophisticated and waste a lot of needed energies. As the modern water coolers uses a compressor to cool down the water temperatures. Figure 1 shows a picture of one existing water cooler.

The design of pottery cooling system of the cooling water will appear by controlling the airflow in measurable space that will increase the efficiency of cooling the water inside the pottery. 


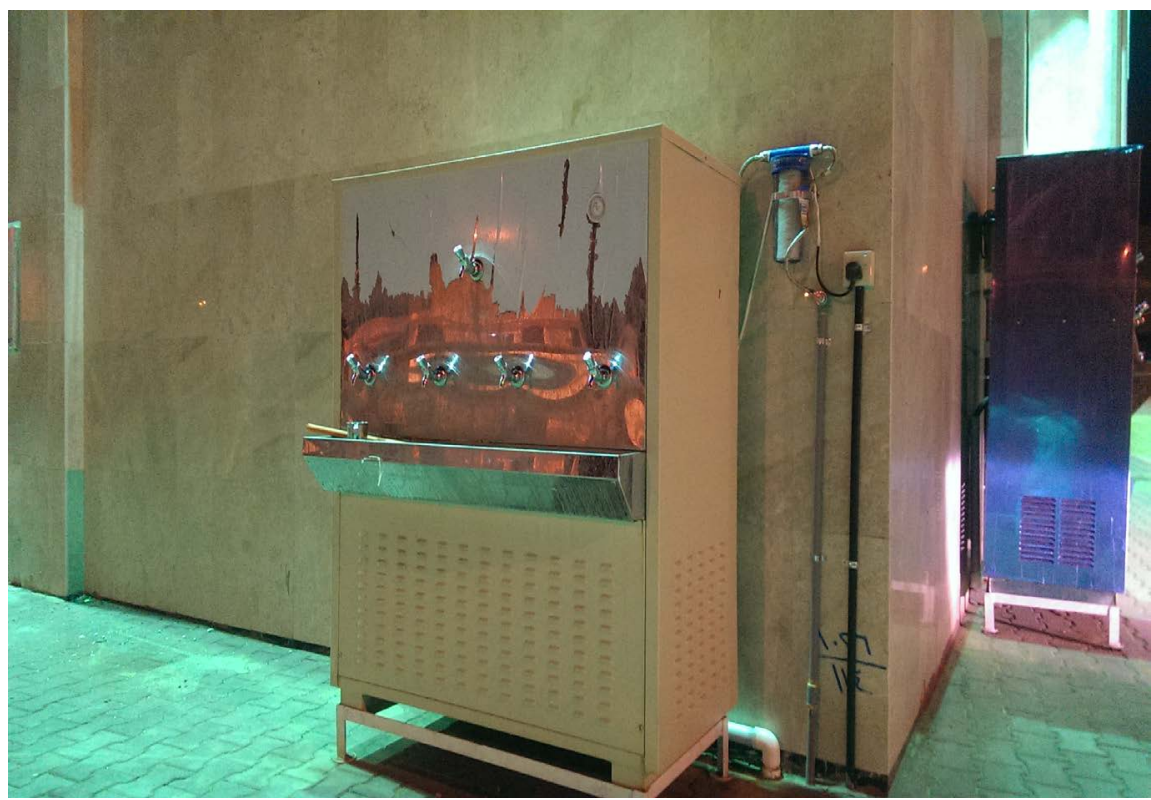

Figure 1. Existing water cooler.

\section{Design Concept}

In this work, we will design, build and test a novel solar powered water cooler. The system consists of pottery made of clay, a classical method to store and cool water in the desert. It also includes a solar panel, two mini fans, thermally sealed box and some pipes to run water through them. Figure 2 illustrates graphically the apparatus used in our design.

The pottery by nature is pores which allows air to leak into the water and cools it. In this case, the fans will be concentrated on the pottery surface to cool the drops of water that appears on surface of the pottery. Therefore heat exchanging process will occur between water droplets and pottery surface. Similarly, the heat exchange will take place inside the pottery as the cold surface will cool down the water inside it. The fans are powered by solar panels that are installed on the side of the box. Then the temperature sensors are placed inside the pottery to take the reading as the temperature will drop and the water will be cooled down. A data acquisition system is imposed into the system to collect the data of the temperature during the entire day.

After the design was established, the system was build and is shown with an outside view and an inside view in Figure 3(a) and Figure 3(b) respectively.

The total cost of the system is shown in Table 1 below.

\section{Calculations and Measurements}

In our study we have adapted the utilization of a data acquisition system that we have imbedded into the pottery. These data acquisition systems have measured the water temperature for the duration of a typical day in Saudi Arabia during the month of August. At this time of the year the outside temperature was recorded to be at $47^{\circ} \mathrm{C}$. Table 2 below represents the data collected between noon 


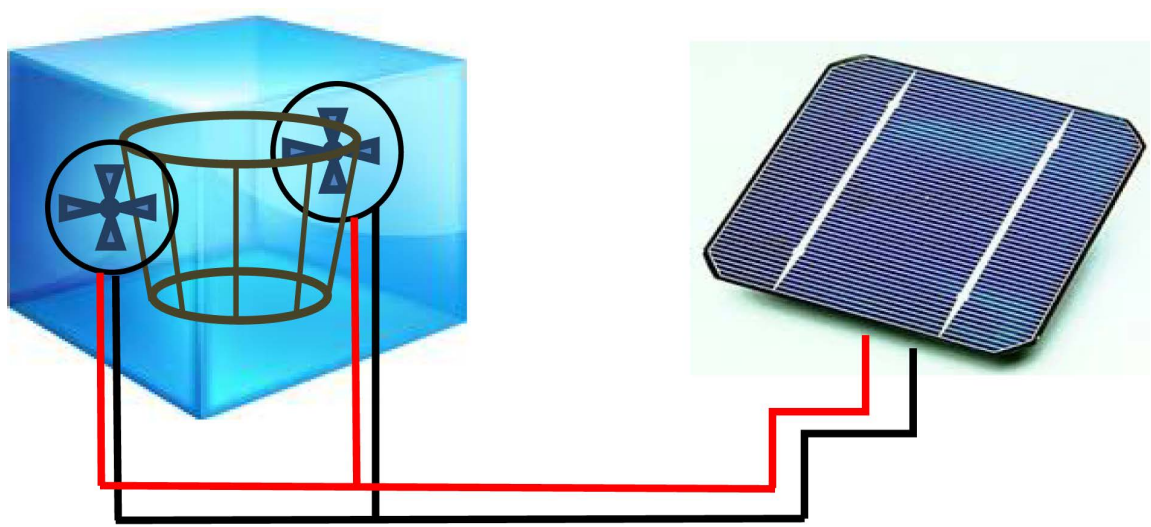

Figure 2. Apparatus used in design.

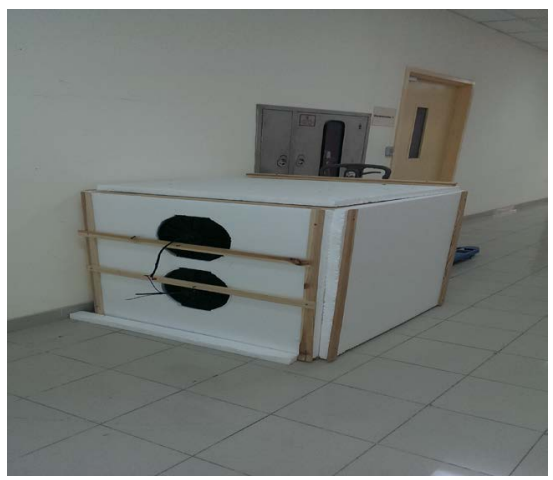

(a)

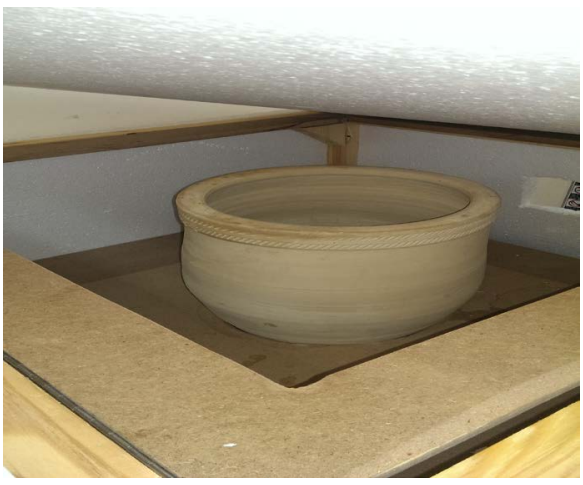

(b)

Figure 3. (a) Outside view of the system; and (b) Inside view of the system.

Table 1. System total cost.

\begin{tabular}{cc}
\hline Item & Price (USD) \\
\hline Pottery & 27 \\
Solar Panels & 100 \\
Fans (2) & 26 \\
Pipes & 7 \\
Sealed Foam Box & 120 \\
Total Cost & $\mathbf{2 8 0}$ \\
\hline
\end{tabular}

till 11 o'clock on the following day for an hourly interval.

\section{Efficiency and Return of Investment (ROI)}

In order to calculate the efficiency, $\eta$, we need to define the initial and final temperatures denoted respectively by, $T_{i}$ and $T_{f}$ Therefore, the efficiency will have the following equation,

$$
\eta=\left[\left(T_{f}-T_{i}\right) / T_{i}\right] \times 100
$$

As a result, we have an average value for the calculated efficiency as $48.19 \%$. 
Table 2. Recorded water temperatures.

\begin{tabular}{cc}
\hline Time & Recorded Temperature \\
\hline Noon Time & 31 \\
$2: 00 \mathrm{pm}$ & 25 \\
$3: 00 \mathrm{pm}$ & 22 \\
$5: 00 \mathrm{pm}$ & 21 \\
$7: 00 \mathrm{pm}$ & 20 \\
$9: 00 \mathrm{pm}$ & 20 \\
$11: 00 \mathrm{pm}$ & 19 \\
$1: 00 \mathrm{am}$ & 19 \\
$3: 00 \mathrm{am}$ & 19 \\
$5: 00 \mathrm{am}$ & 19 \\
$7: 00 \mathrm{am}$ & 18 \\
$9: 00 \mathrm{am}$ & 17 \\
$11: 00 \mathrm{am}$ & 16 \\
\hline
\end{tabular}

\section{[7] [8].}

An important parameter that we should include in our study is the maintenance cost. As with every device, maintenance is an essential part of it. For our device we expect to have minor cleaning maintenance for the solar panels, the fans and the pottery. This is required to be done once a week with an unskilled labour. This is typically a one hour charge of around USD 5.

The rate of return of investment, ROI is calculated to provide the amount of money that it costs versus a typical product that is running in the market today.

Therefore,

$$
\text { ROI }=\frac{\text { Cost of our product }- \text { Cost of typical product in the market }}{\text { Cost of typical product in the market }} .
$$

Thus, the appropriate amount of the novel product cost is provided in Table 1 as USD 280. The operation of 2 years for a conventional water cooler costs around USD 300. Therefore, we would approximate that within two years, the investment would have returned its original cost. And without any additional cost as the power will be consumed from the solar cells [9].

\section{Conclusion}

A typical cooler will cool the water up to $15^{\circ} \mathrm{C}$, with an efficiency of $51.61 \%$. Our cooler has proven to cool the water up to a temperature of $16^{\circ} \mathrm{C}$. These results have shown that the novel method is greener and environmentally safe as well as it has no operational costs. Furthermore, a typical water cooler costs around $\$ 150$, while our novel cooler costs $\$ 280$. The price difference will be compensated by time as it has zero operation cost. Further study will compute the production costs in order to make this novel cooler available in the market. 


\section{References}

[1] Balghouthim, M., et al. (2012) Investigation of a Solar Cooling Installation in Tunisia. Applied Energy, 98, 138-148. https://doi.org/10.1016/j.apenergy.2012.03.017

[2] Otanicar, T., et al. (2013) Prospects for Solar Cooling-An Economic and Environmental Assessment. Solar Energy, 86, 1287-1299.

https://doi.org/10.1016/j.solener.2012.01.020

[3] Hassan, H.Z. and Mohamad, A.A. (2013) A Review on Solar-Powered Closed Physisorption Cooling Systems. Renewable and Sustainable Energy Reviews, 16, 2516-2538. https://doi.org/10.1016/j.rser.2012.02.068

[4] Ajib, S. and Gunther, W. (2013) Solar Thermally Driven Cooling Systems: Some Investigation Results and Perspectives. Energy Conversion and Management, 65, 663-669. https://doi.org/10.1016/j.enconman.2011.09.022

[5] Omajaro, P. and Brektkopf, C. (2013) Direct Expansions Solar Assisted Heat Pumps: A Review of Applications and Recent Research. Renewable \& Sustainable Energy Reviews, 22, 33-45. https://doi.org/10.1016/j.rser.2013.01.029

[6] Wang, R.Z., et al. (2009) Solar Sorption Cooling Systems for Residential Applications: Options and Guidelines. International Journal of Refrigeration, 32, 638-660. https://doi.org/10.1016/j.ijrefrig.2009.02.005

[7] Smith, M.K., et al. (2013) Water Cooling Method to Improve the Performance of Field-Mounted, Insulated, and Concentrating Photovoltaic Modules. Journal of Solar Energy Engineering, 136, Article ID: 034503.

[8] Udaya Ravi, S.A. and Ravikirannline, B.S. (2014) Design and Development of Solar Water Cooler. Industrial Science, 1, 66-73.

[9] Atieh, A. and Al Shariff, S. (2013) Case Study on the Return on Investment (ROI) for Using Renewable Energy to Power-Up Typical House in Saudi Arabia. Sustainable Cities and Society Journal, 17, 56-60. 